\title{
WHAT SHALL WE DO WITH THE DUKE? \\ PUBLIC MEMORY AND CULTURE WARS IN THE SCOTTISH STYLE ${ }^{1}$
}

\section{ALEX TYRRELL}

$\mathrm{D}$ uring the 2002 Christmas season, as Australia moved towards war with Iraq, the Melbourne Age briefly turned aside to provide its readers with news of a different sort of conflict. The newspaper referred to the intensification of what it called 'culture wars' between the Federal Government and the curatorial staff of the National Museum of Australia in Canberra. The disputes included accusations that the museum lionised 'popular culture figures, dissidents and criminals but overlooked nation-building Australians'. More controversial still was a disagreement over the depiction of Aboriginal history. Using terms such as 'political correctness', 'predictable didactism' and 'victim episode', people close to the Government, so it was reported, had objected to the museum's depiction of race relations in Australia. Defenders of the museum had responded by accusing the politicians of trying to impose a more optimistic reading of the nation's past in the form of a 'right-wing agenda, particularly in regard to indigenous issues'.

As anyone who had read the Age over the previous years knew well, these 'culture wars' were no mere excursion into antiquity. They touched on a whole series of controversial issues relating to the claims of Aborigines upon the
Australian polity in such matters as their right to an official apology and the recognition of traditional land ownership. In the words of an Age reporter, the museum had become 'an ideological battleground' where interpretations of the past were inextricably intertwined with views of what should happen in the present and the future. ${ }^{2}$

This dispute over museum policy was reported as one that was taking place uniquely within Australia; the journalists failed to note that they were reporting a local version of an international phenomenon that had been developing during the closing decades of the twentieth century. No longer could the term 'museum' be confined to the prim definition offered by the Encyclopaedia Britannica in 1958: ${ }^{3}$

The museum of today is an institution which exhibits and stores objects of history, art, science, industry and other more specialized categories and in addition may interpret or use these objects to explain trends and developments in the various fields of human knowledge.

As the century closed there was no agreement among scholars over 'trends and developments'; there were no agreed metanarratives of national histories. In 
many parts of the world museums were being built or redesigned as sites of public memory where new and unsettling versions of the past could be set out, often in combative style, and connected with current issues.

The emergence of the new museology exemplified a significant disjunction between academic history and public memory that was attracting scholarly attention. In 1996 a work of seminal importance by Pierre Nora and a team of scholars appeared in an English version. Realms of Memory. Rethinking the French Past (the original work was Lieux de Mémoire), was based on the proposition that academic history is a reconstruction of the past from empirical data whereas public memory belongs to the present and is attached to symbols of community. For Nora the 'analysis and critical discourse' inherent in history as an intellectual discipline make it different from public memory. Unlike history which has no absolutes, public memory 'situates remembrance in a sacred context' and is 'a real part of everyday experience'. It is a form of socially constructed belief that serves as a basis for collective action, and in a pluralist society it is inevitably 'conflictual': to influence public memory is to exercise power. ${ }^{4}$

In Britain during recent decades one sign of the importance attached to public memory has been the remarkable growth of people's museums and other memorial sites where the lives of those who were previously ignored or patronised can be sympathetically portrayed and celebrated: the poor, women, minorities, indigenous peoples and slaves. ${ }^{5}$ In this essay attention will be directed to the north of Scotland where there has been a remarkable efflorescence, not only of museums, but also of memorials promoting a form of public memory that challenges the power and position of an elite which has acquired vast tracts of land since the eighteenth century. The theme to which these museums and other memorials are dedicated is 'the Highland Clearances', the episode in Scottish history that is constructed around a depiction of large numbers of poor men, women and children being displaced from the land of their ancestors to make way for sheep brought in by brutal landlords.

This is a story that has been heavily qualified by historical research. Two recent historians have objected to the 'tone of patronizing compassion' with which the emigrants have usually been described. ${ }^{6}$ Another historian has warned against an undue preoccupation with 'expulsive influences' that have 'stimulated a persistently negative historiography of a Highland diaspora which has often owed as much to persuasion as persecution'. ${ }^{7}$ The museums that have been established to commemorate the Clearances have little to say about this form of historical revisionism; they impart what has been described as 'notions of trauma, dislocation and oppression as well as a sense of loss and betrayal'. Visitors are presented with 'coercive' narratives based on this interpretation. ${ }^{8}$ Evidently this is an example of the disjunction between academic history and public memory to which Nora has referred; the term 'Highland Clearances' has entered the Scottish sense of national identity so strongly as an unmitigated story of wretchedness - it is the subject of novels, paintings and music as well as works of history - that for most people it has been beyond challenge.

During the 1990s several Scottish museums and memorials have served as focal points for the 'conflictual' feeling to 
which this form of public memory can give rise. The example chosen for discussion here is the campaign to destroy or at the very least to contest a statue that seems to emblematise the history of the Clearances. On a pillar 100 feet high and towering over the slopes of Ben Bhraggie near Golspie in Sutherlandshire the first Duke of Sutherland overlooks the vast estates that passed into his hands by marriage in $1785 .{ }^{9}$ An inscription informs the visitor that the monument was erected by 'His Tenantry And Friends' in honour of a man 'Of Loved Revered and Cherished Memory'. ${ }^{10}$

The knowledge that the statue still proclaims this message has become unbearable to Scots in many parts of the world. Few episodes during the Clearances are as well known as the Sutherland Clearances. During the first half of the century large numbers of tenants were displaced from their inland farms to make way for sheep. They were resettled on the coast where they were expected to combine small-holding with labour in the fisheries and other new industries that were set up by the Duke. When these ventures failed, and the potato famine devastated the Highlands, there was massive emigration. ${ }^{11}$

This is a story that has become legendary. It features villains such as the Duke's agents, James Loch and Patrick Sellar. Loch acquired notoriety as 'the Sutherland Metternich', and Sellar was brought to trial accused of brutal evictions in which people were forced to flee when their houses were set ablaze. Sellar was acquitted, but in the words of Eric Richards 'he became the archetypal villain of Highland history'. As told by modern historians, however, this is not the simple story that is embedded in folklore. Richards refers to 'policies ... imposed upon an unwilling population'; 'a series of ugly incidents'; mismanagement; and 'distant condescension'. These helped to give rise to a belief in a 'golden age' of the pre-Clearance past that powerfully influenced opinion in Scotland and was carried to other parts of the world by emigrants. Nonetheless Richards emphasises the realities within which all the participants in this sad story struggled to find solutions. The pressures of a rising population and famine were ineluctable, he points out. The Sutherland family expended a fortune in an attempt to create a vibrant Highland economy. When famine ravaged the area during the 1840s, the Duke mobilized relief 'on an unprecedented scale' and subsidized emigration, often in response to appeals for assistance from the prospective emigrants. ${ }^{12}$ For the modern historian there can be no easy rush to judgment.

Public memory has followed a different course from the one mapped out by revisionist historians. In 1994 a committee called 'The Book of Ben Bhraggie Steering Group' set out to demolish (this was later amended to 'remove') the statue of the Duke. According to the Group's organiser, Sandy Lindsay, the aim was to get rid of 'this symbol of the brutal clearance and dispersal of the Gaels and to replace it with a suitable memorial to the victims of the Highland Clearances'. The 'Book', it was hoped, would eventually contain the names of Scots and the descendants of Scots all over the world. Opposition was expected, and a fund was opened to finance 'a major debate'. ${ }^{13}$

The Steering Group was fortunate in its timing; traditional forms of publicity could be supplemented by the modern devices of the day. Soon the campaign had its own suitably emblazoned teeshirt. ${ }^{14}$ Better still, the use of the internet 


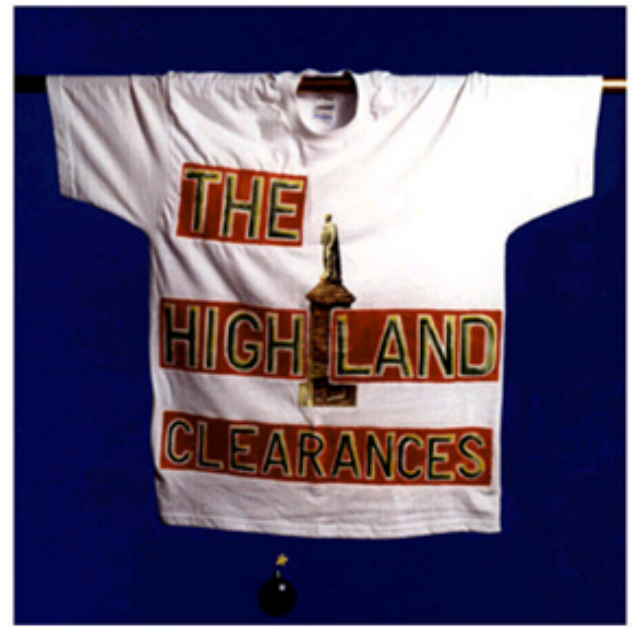

A highland clearances tee-shirt Source: http:// www.Lanntair.com/Exhibitions/MacTotem/ default.htm

was becoming widespread, and Lindsay's appeal for 'debate' was greeted by a remarkable outburst of interest and fulmination. Contributors to web sites some of them bore exotic names such as Mactotem and Nessie's Loch Ness Times waded into the fray. ${ }^{15}$ Often referred to derisively as 'the mannie', the Duke appeared as the autocrat who had forced people from their homes to drift off to the slums of Glasgow and Edinburgh, or to take their chances as emigrants sailing to North America and Australia on ships that were worse than those that had been used for the slave trade. ${ }^{16}$ 'The Duke's horrible long shadow', wrote Janet MacKay in an emailed 'growl for the night', 'darkens all of Canada, the USA with it' ${ }^{17}$ Other web sites noted the rise of a movement in Eastern Europe to expunge the monuments of the Soviet past. The Duke of Sutherland was 'Scotland's own Josef Stalin', one web site proclaimed; it was not surprising that there had been a campaign 'to have the statue smashed and scattered over the hillside' ${ }^{18}$
Removing or destroying statues and memorials for ideological reasons is a new idea in Britain. 'Dépanthéonisation' the wonderfully evocative French term that describes the removal or destruction of the physical remains and statuary of great men who are no longer deemed worthy of veneration in public places has long been a feature of French political life, ${ }^{19}$ but it has not been adopted by the British. There were many disputes, but during the nineteenth-century era of 'statumania' the British procedure was to allow the memorials of great men of divergent political persuasions to share the public space. ${ }^{20}$ This notion still had its upholders in the 1990s. Acknowledging that his first instinct had been to pay for the gelignite needed for demolition, a contributor to a web-page called for the retention of the Duke's statue, 'so long as the sod is surrounded by plaques telling what he did' $^{21}$

'Let the Statues Stand', another webpage similarly demanded: it would be better to leave the statue as a monument, not to the Duke, but to his misdeeds. His 'wealth, power and vanity are enshrined in stone and should be preserved as warnings to future generations to beware of allowing such circumstances to happen again'. Warming to his task, the writer warned that the removal of the Duke's statue would set a bad precedent. Already a town councillor in another part of Scotland had called for the destruction of a famous castle, because it was 'a relic of the feudal system'. Parties of the right and the left might embark on a 'tit-fortat' battle against memorials. Worse still, 'women's groups' might cast their baleful gaze across Edinburgh and call for the removal of the memorials honouring Sir Walter Scott and other men of eminence. There might even be 'a top of the pops 
reassessment' that would see Edinburgh cleared of its existing monuments and endowed with replacements in honour of Billy Connolly, the famous footballers of the day and 'stars of the television soaps'. It would be better to leave the Duke's statue standing exposed to the bitter winds of Sutherland. ${ }^{22}$

When the petition to remove the Duke from his perch was officially rejected by the Divisional Planning Committee of the Golspie Community Council, the monument campaign moved on to a new phase. As part of its original application the Steering Group had called on the local authority to install 'information panels' that would provide a suitable commentary on the Duke's life and times. This approach to correcting the presentation of the past has not been adopted, but it was soon taken further: if the Duke could not be removed, he could be confronted by his victims. A Clearances Memorial Project is currently creating a museum, visitor centre and sculpture near Helmsdale, a town a few miles north of Golspie. The sculpture will stand on Creag Bun-Uillidh which is lower than Ben Bhraggie, but it will be 30 $\mathrm{ft}$ high on a $90 \mathrm{ft}$ plinth making it higher than the Duke's monument. It will show an evicted family consisting of father, son, mother and baby. The sculptor, Gerald Laing, envisaged the Duke looking into the distance and seeing his victims 'coming over the hill'. Laing had drawn inspiration, he added, from the biblical story of the expulsion from the Garden of Eden and from his own childhood memories of being bombed during the Second World War. Mixing his metaphors more than slightly, he went on to say that he had sculpted the woman as a beautiful 'Madonna'. Advance publicity has intimated that visitors are to approach this monument along a series of standing stones with inscriptions telling the story of the Clearances. The Centre is also to contain a 'Wall of Descendants' containing the names of those who fulfil two criteria: an appropriate donation to the project and a statement that 'you believe that one of your ancestors was cleared from their homes in the Highlands and Islands whether by eviction or economic hardship'. ${ }^{23}$

The project has a businessman sponsor, Dennis MacLeod, whose vision sits uneasily with the attitude of those who had led the campaign to topple the Duke. The new site of memory, he insists, is an attempt at closure of the issues raised by the Clearances: it will show all sides of the story, and it will heal the bitterness bequeathed by the past. There will be no attempt to associate it with a demand for 'retribution' from presentday landowners. ${ }^{24}$ He hoped for too much. It was always unlikely that the land issue could be ignored. Like Australia, Scotland conducts its 'cultural wars' with an eye to the future. The attempt to topple the Duke may have failed, but some campaigners have taken consolation from the passions they have aroused in favour of 'atonement' for the 'unfinished business' of the Highland Clearances. ${ }^{25} \mathrm{As}$ they knew, few issues in modern Scottish life blend the past with the present more thoroughly than disputes over land rights. Nineteenth-century Scotland, writes Thomas Devine, 'had the most concentrated pattern of private landownership in Europe': '659 individuals owned $80 \%$ of Scotland'. Among them was the Duke of Sutherland who owned over a million acres. This pattern continues into the present day. ${ }^{26}$

Recently some of the Highland 
communities have attempted to buy the lands that they rent from these landed magnates, but they have struggled to find the resources required to bid successfully on the free market. With the resurgence of a strong sense of Scottish national identity and the restoration of a Scottish parliament in 1999 this issue has come to the fore. For the Scottish National Party (SNP), the principal Opposition party in the new parliament, the land question is symbolic as well as substantial, because ownership of Highland estates has often passed into the hands of Englishmen and absentee landlords. In discussions of this sort the Sutherland estates soon come to mind; the first Duke, was George Granville-Leveson Gower, the second Marquis of Stafford, who became a Scottish landowner only by marriage. Significantly, Sandy Lindsay, the inspirer of the Book of Ben Bhraggie Steering Group, was a former SNP councillor, and Rob Gibson, who also campaigned against 'the Murderer's Monument' had been the SNP's land use spokesman. ${ }^{27}$ One of Lindsay's aims was to create 'an important record of national feeling' ${ }^{2}{ }^{28}$ Evidently, to topple the Duke is to topple the ascendancy of the alien monarchs of the glen.

The Scottish National Party is not the only major party to take up the land issue - the Labour Party and the Liberal Democrats, who together form the Scottish Government, agree with the SNP that the laws of land ownership should be altered in favour of local communities. In January 2003 a Land Reform Bill passed through the Scottish Parliament. The Bill made major changes in Scots Law: it allowed a 'right to roam' over almost all the land of Scotland including the Queen's estate at Balmoral; it gave communities first refusal on land that was offered for sale; and it gave crofters the right to force land sales. ${ }^{29}$

A start had been made even before the passing of the Act. With the help of grants from the Scottish Land Fund and the Highland and Islands Enterprise Community Land Unit, 91 projects had been commenced in the previous two years. ${ }^{30}$ One of these was the purchase of the island of Gigha by its inhabitants. On 21 July 2002 they marked their takeover by commencing the construction of a monument that was humbler than the Duke's pillar but spoke volumes for the changing outlook of a new era. Laying the first stone of a cairn, the deputy First Minister of Scotland spoke of the monument as a symbol that the islanders were no longer the hapless victims of the historical past but a community with the agency needed to face the challenge of the future. $^{31}$

\section{ENDNOTES}

1 This essay first appeared in Passim. The Magazine of the La Trobe University History Society, no. 1, 2003. It appears here (slightly altered) with the permission of the editors. The concepts on which the essay is based are discussed at greater length in Alex Tyrrell's contributions to Contested Sites. Commemoration, Memorial and Popular Politics in Nineteenth-Century Britain, Aldershot: Ashgate, 2004, co-authored with Dr Paul Pickering and others.

2 The references to the Age in the previous paragraphs come from the issues for 2730 December 2002.

3 Encyclopaedia Britannica, London, 1958, vol. 15, p. 994.

4 P. Nora, Realms of Memory, Rethinking the French Past, New York, Columbia University Press, 1996, vol. 1, pp. xii, 3. 
5 Examples of these museums are The People's Story (Edinburgh); The People's History Museum (Manchester) and The Transatlantic Slavery Gallery in the Merseyside Maritime Museum (Liverpool).

6 R. A. Houston \& W.W.J. Knox, The New Penguin History of Scotland, London, 2001, p. xxxii.

7 M. D. Harper, 'Clearances of the Highlands and Islands' in M. Lynch (ed.) The Oxford Companion to Scottish History, Oxford, 2001, p. 230.

8 L. Gourievidis, 'Representing the Disputed Past of Northern Scotland', History and Memory: Studies in Representations of the Past, Fall-Winter 2000, 3 (4), pp. 7-9.

9 He was created Duke in 1833, but for the sake of simplicity he is referred to as 'the Duke' throughout this essay.

10 Information taken on site by Alex Tyrrell. The statue was described in the Edinburgh Evening Post, 15 July 1837 (quoting the Inverness Courier) as 'the highest statue in Britain, or we believe in Europe ... forming a conspicuous landmark far and near, by sea and land, on both sides of the Moray Firth'. Sir Francis Chantrey was the sculptor.

11 Ewen Cameron, 'Clearances of the Highlands and Islands' in Lynch (ed.), The Oxford Companion to Scottish History, p. 97

12 E. Richards, Leviathan of Wealth. The Sutherland Fortune in the Industrial Revolution, London, 1973, pp. 266, 28688

13 'Fax: from Sandy Lindsay to Janet Mackay, June 13, 1995' in The Book of Ben Bhraggie, http://www.Chebucto.ns.ca/ Heritage/FSCNS/Scots_NS/Thr_Yrs/ DukeSuth/Book_Ben_B [accessed 15/ 04/2003].
14 'Reviewing the Duke of Sutherland Monument: 1998' in MacTotem, http:// www.Lanntair.com/Exhibitions/ MacTotem/default.htm [accessed 15/ 04/2003].

15 The best of the website entries seems to be Paul Basu, Narratives in a Landscape. Monuments and memories of the Sutherland Clearances, http:/ / www.btinternet.com/ paulbasu/ narratives/nl-title.html

16 'Should the Duke of Sutherland Remain?', http:/ / www.Chebucto.ns.ca/ Heritage/FSCNS/Scots_NS/Thr_Yrs/ Duke_Sutherland.html [accessed 15/04/ 2003].

17 'Janet Mackay's initial reaction' in That Statue Must Go!, http:// www.Chebucto.ns.ca/Heritage/ FSCNS/Scots_NS/Thr_Yrs/DukeSuth/ JMK_2_AMK [accessed 15/04/2003].

18 Sutherland Monument, http:/ / www.unique-cottages.co.uk/guide/ highland_region/east_coast/ north_to_wick/golsp [accessed 15/04/ 03].

19 See T. Laqueur, 'In and Out of the Panth,on', London Review of Books, 23 (18), September 2001, p. 6; A. Ben-Amos, Funerals, Politics and Memory in Modern France,1789-1996, Oxford 2000.

20 This point is developed more fully by Alex Tyrrell (with Michael Davis) in 'Bearding the Tories. The Commemoration of the Scottish Political Martyrs of 1793-94' in Pickering \& Tyrrell, Contested Sites. Commemoration, Memorial and Popular Politics in Nineteenth-Century Britain, chapter 2.

21 The Statue Must Stand; Surrounded by Interpretive Plaques, http:// www.Chebucto.ns.ca/Heritage/ FSCNS/Scots_NS/Thr_Yrs/DukeSuth/ TMR_2_AM [accessed 15/04/2003].

22 'Let the Statues Stand', http:/ / 
www.Chebucto.ns.ca/Heritage/

FSCNS/Scots_NS/Thr_Yrs/Duke_Suth/

Statue_Stand [accessed 15/04/2003].

23 For the Helmsdale project see Scots, The Journal of the Scots Heritage Society, n.d. nos $17,18,19$.

24 Scots, The Journal of the Scots Heritage Society, no. 17, pp. 20-21.

25 R. Gibson, Toppling the Duke: Outrage on Ben Bhraggie?, Evanton, 1996, p. 52, quoted by Basu, Narratives in a Landscape, http://www.btinternet.com/ $\sim$ paulbasu/narratives/nl-text05.html

26 T. Devine, The Scottish Nation 1700-2000, London, 1999, pp. 449, 457-58.

27 'Highland Clearances Campaign' in Nessie's Loch Ness Times, 24/6/2000, http://www.the frasers.com/nessie/ news/nesspapr624.html [accessed 15/ 04/2003].

28 'Fax: from Sandy Lindsay to Janet Mackay, June 13, 1995' in The Book of Ben Bhraggie, http://www.Chebucto.ns.ca/ Heritage/FSCNS/Scots_NS/Thr_Yrs/ DukeSuth/Book_Ben_B [accessed 15/ 04/2003].

29 Scotsman, 24 January 2003.

30 Scotsman, 24 January 2003.

31 Scotsman, 24 July 2002. 